\title{
PENGARUH MODEL RECIPROCAL TEACHING BERBANTUAN MASALAH AUTENTIK TERHADAP KEMAMPUAN PEMECAHAN MASALAH DAN KONEKSI MATEMATIS SISWA
}

\author{
Oleh : \\ *Ni Made Erlinta Devi ${ }^{1)}$, I Wayan Puja Astawa ${ }^{2)}$, Sariyasa ${ }^{3)}$ \\ Fakultas Matematika dan Ilmu Pengetahuan Alam, Universitas Pendidikan Ganesha ${ }^{1.2 .3)}$ \\ devierlinta@gmail.com
}

\begin{abstract}
Abstrak
Penelitian ini bertujuan untuk membandingkan kemampuan pemecahan masalah dan koneksi matematis siswa yang mengikuti model reciprocal teaching berbantuan masalah autentik dengan siswa yang mengikuti pembelajaran konvensional. Penelitian eksperimen semu dengan rancangan post-test only control group design ini memiliki sampel sebanyak 75 siswa, yang dibagi menjadi dua kelompok. Kelompok eksperimen mengikuti model reciprocal teaching berbantuan masalah autentik sedangkan kelompok kontrol mengikuti pembelajaran konvensional. Data dikumpulkan dengan teknik tes dan dianalisis menggunakan uji Manova. Hasil penelitian menunjukkan bahwa kemampuan pemecahan masalah dan koneksi matematis siswa yang mengikuti model pembelajaran reciprocal teaching berbantuan masalah autentik lebih tinggi dari pada kemampuan pemecahan masalah dan koneksi matematis siswa yang mengikuti pembelajaran konvensional $(F=4.310, p(0,014)$. Dengan demikian, dapat disimpulkan bahwa model reciprocal teaching berbantuan masalah autentik berpengaruh positif terhadap kemampuan pemecahan masalah dan koneksi matematis.
\end{abstract}

Kata kunci : reciprocal teaching, masalah autentik, pemecahan masalah, koneksi matematis.

\section{Abstract}

This study aimed to compare problem solving ability and mathematical connection of students who were learned using reciprocal teaching model with authentic problems and students who were learned using conventional learning. This research applied quasi experiment method with control only group design. The sample of this study consisted of 75 junior high school students who are divided into two groups. The experimental group was learned using reciprocal teaching model with authentic problems and the control group received conventional learning. The data was collected using test and analized using Manova. The result showed that problem solving abilities and mathematical connection of students who were learned using reciprocal teaching model with authentic problems were higher than students who were learned by conventional learning $(F=4.310, p(0,014)$. Thus, it can be concluded that the reciprocal teaching model with authentic problem has positive effect on problem solving abilities and mathematical connection of students.

\section{Keywords: Reciprocal Teaching, Authentic Problem, Problem Solving, Mathematical Connection.}

\section{PENDAHULUAN}

Berbagai inovasi pembelajaran matematika telah banyak dilakukan, seperti pembelajaran dengan konstruktivisme (Riyanto, 2011), pembelajaran kooperatif (Whicker, Boll \& Nunnmery, 2010), dan pembelajaran berbasis teknologi (Sudiarta et al., 2018; Sudiarta dan Sukawijaya, 2018). Inovasi pembelajaran tersebut dilakukan untuk mencapai tujuan pembelajaran matematika. Namun dalam kenyataannya masalah pembelajaran matematika masih saja ditemui.

National Council Of Teacher Of Mathematics (NCTM) menetapkan lima standar kemampuan matematis yang harus dimiliki oleh siswa, yaitu kemampuan pemecahan masalah/problem solving, kemampuan komunikasi/communication, kemampuan koneksi/connection, kemampuan penalaran/reasoning, dan kemampuan representasi/representation. Berdasarkan uraian tersebut, pemecahan masalah dan koneksi matematis merupakan kemampuan wajib yang harus dikembangkan dan dimiliki oleh siswa.

Pemecahan masalah adalah salah satu aktivitas kognitif yang dapat diterapkan individu dalam berbagai konteks yang berhubungan dengan gaya hidup, terutama berkenaan dengan gaya hidup yang cepat, revolusi 
teknologi informasi dan perubahan yang dipercepat dalam semua aspek kehidupan (Aljaberi \& Gheith, 2016). Kolovou (2011) mengatakan bahwa tujuan utama pendidikan matematika adalah agar siswa mampu memecahkan masalah secara independen. Namun tidak bisa dipungkiri bahwa kemampuan siswa Indonesia dalam memecahkan masalah matematika masih sangat memprihatinkan. Berdasarkan hasil survei yang dilakukan pada tahun 2015 ditemukan bahwa dari 70 negara yang berpartisipasi, kemampuan matematika siswa Indonesia berada pada peringkat 63, kalah jauh dibanding Vietnam yang ada di peringkat 12 dan Singapura di peringkat pertama (OECD, 2016). Bana Kartasasmita (2017) mengungkapkan Singapura berada di peringkat pertama dalam survei PISA karena pengajaran matematikanya bertumpu pada soal cerita dan pemecahan masalah.

Selain kemampuan pemecahan masalah, siswa juga wajib menguasai kemampuan koneksi matematis. Koneksi matematis adalah keterkaitan matematika secara internal dan eksternal (Listyotami , 2011). Keterkaitan secara internal adalah keterkaitan antara konsep-konsep di dalam matematika itu sendiri, sedangkan keterkaitan secara eksternal, yaitu keterkaitan antara matematika dengan ilmu-ilmu lainnya serta kehidupan sehari-hari.

Ruspiani (2000) menyatakan bahwa, kemampuan siswa dalam melakukan koneksi matematis masih tergolong rendah. Ruspiani mengungkapkan, nilai rata-rata kemampuan koneksi matematis siswa sekolah menengah di Indonesia yaitu sekitar $22,2 \%$ untuk koneksi matematis antara sesama materi di pelajaran matematika, 44,9\% untuk koneksi matematis antara matematika dengan bidang studi lain, dan 67,3\% untuk koneksi matematis antara matematika dengan kehidupan sehari-hari.

Inovasi dalam proses pembelajaran matematika sangat diperlukan. Contohnya, membuat siswa berperan aktif dalam pembelajaran. Salah satu alternatif model pembelajaran yang bisa digunakan adalah reciprocal teaching. Reciprocal teaching merupakan model pembelajaran yang menekankan siswa unuk membaca, menggali dan mengkontruksi pembelajaran matematika sehingga tidak menerima dari guru saja, melainkan harus mencari sendiri pengetahuan sendiri. Dalam menerapkan model reciprocal teaching memiliki empat langkah yaitu merangkum, menyusun pertanyaan, memprediksi jawaban dan menjelaskan kembali.

Beberapa hasil penelitian pun menunjukkan bahwa bahwa model pembelajaran reciprocal teaching efektif digunakan dalam pembelajaran matematika. Pertama, Herlambang, dkk (2015) menyatakan bahwa kemampuan komunikasi matematis siswa yang mengikuti model reciprocal teaching lebih baik daripada model konvensional dan siswa bersikap positif terhadap pelaksanaan pembelajaran matematika dengan model reciprocal teaching. Kedua, Herman (2014) menyatakan bahwa pemahaman konsep matematika siswa yang mengikuti model reciprocal teaching lebih baik daripada model konvensional. Hal ini terjadi karena dengan model reciprocal teaching, siswa dilibatkan secara langsung untuk menyelidiki konsep yang dipelajari.

Dalam penerapan model reciprocal teaching, perlu diawali dengan memberikan permasalahanpermasalahan yang akrab dengan kehidupan sehari-hari siswa (masalah autentik). Masalah autentik adalah masalah yang dikaitkan dengan pengalamaan riil dunia nyata (real world) siswa (Trianto, 2009). Hal ini bertujuan untuk menumbuhkan motivasi siswa dan memudahkan siswa dalam memahami masalah yang diberikan.

Berdasarkan pemaparan di atas, penulis mencoba untuk melihat pengaruh yang ditimbulkan terhadap kemampuan pemecahan masalah dan koneksi matematis siswa dengan menerapkan model reciprocal teaching berbantuan masalah autentik.

\section{METODE PENELITIAN}

Penelitian ini merupakan penelitian eksperimen semu (quasi experiment), dengan rancangan post test only control group design. Populasi dalam penelitian ini adalah seluruh siswa kelas VII SMP Negeri 1 Mengwi tahun pelajaran 2017/208 yang terdiri dari 11 kelas. Sampel penelitian sebanyak 2 kelas diperoleh dengan menggunakan teknik cluster random sampling dengan melakukan pengundian terhadap seluruh populasi. Berdasarkan pengundian yang telah dilakukan diperoleh kelas VII J sebagai kelas eksperimen dan kelas VII K sebagai kelas kontrol, selanjutnya kedua kelas diuji kesetaraannya menggunakan uji t dan diperoleh hasil bahwa kedua kelas setara. Kelas eksperimen diberi perlakuan berupa penerapan model pembelajaran reciprocal teaching berbantuan masalah autentik dan kelas kontrol diberi perlakuan berupa penerapan pembelajaran konvensional. Pada pertemuan terakhir kedua kelas diberi post-test yang sama.

Ada dua jenis variabel yang terlibat dalam penelitian ini, yaitu variabel bebas (independent variable) dan variabel terikat (dependent variable). Variabel bebas dalam penelitian ini adalah model pembelajaran reciprocal teaching dan variabel terikat dalam penelitian ini adalah kemampuan pemecahan masalah dan koneksi matematis.

Instrumen yang digunakan untuk memperoleh data kemampuan pemecahan masalah adalah instrumen tes berupa tes kemampuan pemecahan masalah yang terdiri dari 4 butir soal uraian. Adapun indikator-indikator dari tes kemampuan pemecahan masalah terdapat pada Tabel 1 berikut. 
Tabel 1. Indikator Tes Kemampuan Pemecahan Masalah

\begin{tabular}{ll}
\hline No & Indikator \\
\hline 1 & Memahami masalah \\
2 & Membuat rencana penyelesaian masalah \\
3 & Menyelesaikan masalah \\
4 & Memeriksa kembali \\
\hline
\end{tabular}

Instrumen yang digunakan untuk memperoleh data kemampuan koneksi matematis adalah instrumen tes berupa tes kemampuan koneksi matematis yang terdiri dari 4 butir soal uraian. Adapun indikator-indikator dari tes kemampuan koneksi matematis terdapat pada Tabel 2 berikut.

Tabel 2. Indikator Tes Kemampuan Koneksi Matematis

\begin{tabular}{ll}
\hline No & Indikator \\
\hline 1 & Mengenali dan memanfaatkan hubungan-hubungan antara gagasan dalam matematika. \\
2 & $\begin{array}{l}\text { Memahami bagaimana gagasan-gagasan dalam matematika saling berhubungan dan } \\
\text { mendasari satu sama lain untuk menghasilkan suatu keutuhan koheren. }\end{array}$ \\
3 & Mengenali dan menerapkan matematika dalam kontek-konteks di luar matematika \\
\hline
\end{tabular}

Dimodifikasi dari NCTM (2000)

Berdasarkan hasil uji validitas, butir soal yang valid dianalisis untuk mengetahui besar koefisien reliabilitasnya. Berdasarkan hasil perhitungan tersebut diperoleh koefisien reliabilitas instrumen untuk tes kemampuan pemecahan masalah sebesar 0.63 dan koefisien reliabilitas instrumen untuk koneksi matematis sebesar 0,72. Dari kriteria yang telah ditetapkan, butir-butir soal tersebut memiliki derajat reliabilitas tinggi.

Karena penelitian ini melibatkan satu variabel bebas dan dua variable terikat maka analisis data dilakukan dengan menggunakan uji Manova satu ekor pada taraf signifikansi 5\%. Sebelum melakukan uji manova terlebih dahulu dilakukan pengujian terhadap normalitas bivariat, homogentias varian, homogenitas matriks varian/kovarian, dan korelasi antar variabel terikat. (Candiasa, 2010).

\section{HASIL DAN PEMBAHASAN}

Data hasil penelitian dianalisis dengan bantuan software SPSS. Data kemampuan pemecahan masalah dan koneksi matematis siswa diberikan kepada kedua kelas sampel dapat dilihat pada Tabel 3 berikut.

Tabel 3. Data Hasil Penelitian

\begin{tabular}{llcccc}
\hline \multirow{2}{*}{ No. } & \multirow{2}{*}{ Variabel } & \multicolumn{3}{c}{ Pemecahan Masalah } & \multicolumn{2}{c}{ Koneksi Matematis } \\
\cline { 3 - 6 } & & Ekperimen & Kontrol & Ekperimen & Kontrol \\
\cline { 2 - 6 } & & 37 & 38 & 37 & 38 \\
2. & $\bar{X}$ & 85.49 & 76.58 & 87.49 & 76.58 \\
3. & SD & 4.09 & 4.62 & 5.57 & 4.79 \\
\hline
\end{tabular}

Selanjutnya, normalitas bivariat, homegenitas varian, homogenitas matrix varian/covarian, dan korelasi antar antar variabel terikat dilakukan sebelum melakukan uji Manova.

Dari hasil uji SPSS, nilai Pearson Correlation Mahalanobis Distance untuk kelas eksperimen diperoleh sebesar 0.803 dan kelas kontrol sebesar 0.525 dengan taraf signifikansi 0,000 lebih kecil dari nilai signifikansi $5 \%$. Sehingga disimpulkan bahwa data berasal dari populasi yang berdistribusi normal bivariat.

Selanjutnya, hasil perhitungan homogenitas varians yang diuji dengan uji Levene menunjukkan nilai sig. yang lebih besar dari nilai signifikansi 5\%. Rangkuman pengujian homogenitas sebaran data dapat dilihat pada Tabel 4

Table 4. Rangkuman Pengujian Homogenitas Sebaran Data

\begin{tabular}{|c|c|c|c|c|}
\hline \multicolumn{5}{|c|}{ Levene's Test of Equality of Error Variances ${ }^{a}$} \\
\hline Variabel Terikat & $\mathbf{F}$ & $\mathbf{d f}_{1}$ & $\mathbf{d f}_{2}$ & Sig. \\
\hline Pemecahan Masalah & .113 & 1 & 73 & .738 \\
\hline Koneksi Matematis & .006 & 1 & 73 & .939 \\
\hline
\end{tabular}


Berdasarkan hasil di atas, dapat disimpulkan bahwa kemampuan pemecahan masalah dan koneksi matematis kelas eksperimen dan kelas kontrol memiliki varians yang homogen. Kemudian, diperoleh matriks varians/kovarians kelas eksperimen dan kontrol sebagai berikut:

$$
\begin{aligned}
\text { Kelas eksperimen } & =\left[\begin{array}{cc}
44.20 & 56.33 \\
56.33 & 165.80
\end{array}\right] \\
\text { Kelas kontrol } & =\left[\begin{array}{cc}
50.20 & 72.01 \\
72.01 & 191.98
\end{array}\right]
\end{aligned}
$$

Hasil pengujian matriks varian kovarian dirangkum pada Tabel 5 di bawah.

Table 5 . Rangkuman Pengujian Box's M

\begin{tabular}{ll}
\hline & Box's Test of Equality of Covariance Matrices $^{\mathbf{a}}$ \\
\hline Box's M & .824 \\
F & .266 \\
df1 & 3 \\
df2 & $9.823 E 5$ \\
Sig. & .850 \\
\hline
\end{tabular}

Nilai sig. yang diperoleh lebih besar dari 5\%. Oleh karena itu, dapat dikatakan bahwa matriks varians/kovarian antar variabel terikat homogen.

Selanjutnya, korelasi product moment digunakan untuk menguji korelasi antara sesama variabel terikat. Hasil pengujian tersebut tertera pada Tabel 6 dan Tabel 7. 
Tabel 6. Rangkuman Pengujian Korelasi Variabel Terikat Kelas Eksperimen

Correlations

\begin{tabular}{llrr}
\hline & & Pemecahan Masalah & Koneksi Matematis \\
\hline Pemecahan & Pearson Correlation & 1 & $.752^{* *}$ \\
Masalah & Sig. (2-tailed) & & .000 \\
& $\mathrm{~N}$ & 37 & 37 \\
\hline Koneksi & Pearson Correlation & $.752^{* *}$ & 1 \\
Matematis & Sig. (2-tailed) & .000 & 37 \\
& $\mathrm{~N}$ & 37 &
\end{tabular}

Dari tabel di atas menunjukkan bahwa kemampuan pemecahan masalah dan koneksi matematis siswa di kelompok eksperimen berkorelasi dengan koefisien korelasi sebesar 0,752 .

Tabel 7. Rangkuman Pengujian Korelasi Variabel Terikat Kelas Kontrol

\section{Correlations}

\begin{tabular}{llrr}
\hline & & Pemecahan Masalah & Koneksi Matematis \\
\hline $\begin{array}{l}\text { Pemecahan } \\
\text { Masalah }\end{array}$ & Pearson Correlation & 1 & $.625^{* *}$ \\
& Sig. (2-tailed) & & .000 \\
& $\mathrm{~N}$ & 38 & 38 \\
\hline Koneksi & Pearson Correlation & $.625^{* *}$ & 1 \\
Matematis & Sig. (2-tailed) & .000 & 38 \\
& $\mathrm{~N}$ & 38 & \\
\hline
\end{tabular}

Dari tabel di atas menunjukkan bahwa kemampuan pemecahan masalah dan koneksi matematis siswa di kelompok eksperimen berkorelasi dengan koefisien korelasi sebesar 0,752.

Tabel 8. Hasil Analisis Dengan MANOVA

\begin{tabular}{lcccccc}
\hline \multicolumn{7}{c}{ Multivariate Tests $^{\mathbf{b}}$} \\
& & Value & F & Hypothesis df & Error df & Sig. \\
Intercept & Wilks' Lambda & .008 & $4300.294^{\mathrm{a}}$ & 2.000 & 68.000 & .000 \\
Kelas & Wilks' Lambda & .885 & $4.310^{\mathrm{a}}$ & 2.000 & 68.000 & .014
\end{tabular}

Berdasarkan tabel diperoleh nilai-nilai statistik Wilks'Lambda, nilai $\mathrm{F}=4.310^{\mathrm{a}}$, serta memiliki signifikansi 0.014 yang kurang dari $0,025(p<0,025)$. Hasil ini dijadikan dasar keputusan dalam menerima $\mathrm{H}_{1}$. Hal ini berarti bahwa kemampuan pemecahan masalah dan koneksi matematis siswa yang mengikuti model pembelajaran reciprocal teaching berbantuan masalah autentik lebih tinggi daripada kemampuan pemecahan masalah dan koneksi matematis siswa mengikuti pembelajaran konvensional.

Dari hasil uji manova yang telah dilakukan tersebut dapat disimpulkan bahwa kemampuan pemecahan masalah dan koneksi matematis siswa secara signifikan dipengaruhi oleh model pembelajaran yang digunakan. Hasil analisis deskriptif dan uji analisis varians multivariat (MANOVA) yang telah dilakukan menjadi dasar penarikan kesimpulan bahwa pembelajaran dengan model pembelajaran reciprocal teaching berbantuan masalah autentik memberikan pengaruh yang baik terhadap kemampuan pemecahan masalah dan koneksi matematis siswa pada materi aritmatika social kelas VII SMP N 1 Mengwi dibandingkan dengan pembelajaran konvensional. 
Model reciprocal Teaching yang dilakukan melalui diskusi kelompok mampu memberikan efek positif terhadap kemampuan pemecahan masalah dan koneksi matematis siswa. Seluruh siswa merasa ikut dilibatkan dalam proses pembelajaran sehingga setiap siswa terdorong untuk lebih berperan aktif. Siswa dilatih untuk mampu mengingat pengetahuan yang telah dipelajari sebelumnya, membuat rangkuman atas materi yang sedang dipelajari, membuat pertanyaan dari rangkuman tersebut, memprediksi jawaban atas pertanyaan yang dibuat, dan menjelaskan kembali isi materi tersebut. Pemberian masalah autentik pada LKS diharapkan dapat membantu siswa untuk mengidentifikasi informasi yang diberikan dan dapat lebih memahami materi dengan baik. Siswa juga dapat menghubungkan materi yang mereka pelajari dengan topik lain maupun dalam kehidupan sehari - hari melalui LKS sehingga kemampuan pemecahan masalah dan koneksi matematisnya meningkat.

Dalam pembelajaran, peneliti membantu memperluas pengetahuan siswa dengan memberikan soal - soal yang berkaitan dengan masalah autentik. Masalah autentik adalah masalah yang dikaitkan dengan pengalaman riil dunia nyata siswa, sehingga siswa benar - benar mengerti keterkaitan topik yang siswa pelajari saat itu dengan topik lain maupun dengan kehidupan sehari - hari. Peneliti juga memberikan penekanan kepada siswa untuk selalu menuliskan apa yang diketahui dan ditanya pada soal - soal terebut. Hal ini juga menjadi salah satu penyebab meningkatnya kemampuan pemecahan masalah dan koneksi matematis siswa.

Pada pembelajaran yang telah dilaksanakan, terdapat empat tahap yang disusun, yaitu meringkas, menyusun pertanyaan, memprediksi jawaban, dan menjelaskan kembali.

1. Pada tahap meringkas, siswa diberikan kesempatan untuk mempelajari materi secara mandiri, selanjutnya merangkum materi tersebut. Rangkuman yang mereka buat berupa ungkapan materi tersebut dalam bahasa mereka sendiri maupun segala informasi tentang materi tersebut yang mereka dapat dari sumber lain. Penggunaan bahasa sendiri mampu meningkatkan pemahaman siswa terhadap materi tersebut. Nantinya, ringkasan yang mereka buat akan dibawa pada saat diskusi kelompok.

2. Tahap menyusun pertanyaan, pada tahap ini siswa menyusun pertanyaan berdasarkan apa yang sudah dirangkum, siswa menyusun beberapa pertanyaan. Siswa dirangsang untuk berpikir dan membuka wawasannya mengenai materi tersebut, keterkaitan dengan konsep - konsep sebelumnya, maupun aplikasinya dalam ilmu lain dalam kehidupan sehari - hari.

3. Tahap selanjutnya adalah memprediksi jawaban, pada tahap ini siswa diberikan kesempatan menyelesaikan pertanyaan yang sudah mereka buat sendiri melalui diskusi kelompok dan LKS. Siswa dapat mengasah kemampuan bernalarnya dan menemukan jawaban atas pertanyaannya sendiri. Jawaban tersebut didapat dengan mengaitkan materi yang diperoleh melalui ringkasan yang sudah mereka buat dan hasil diskusi kelompok yang sudah dilakukan bersama siswa lainnya. Cara tersebut mampu meningkatkan kemampuan siswa dalam melihat keterkaitan hubungan antar konsep yang mereka dapat sebelumnya dan materi yang sedang mereka pelajari. Melalui LKS siswa juga menjadi tahu aplikasi materi tersebut dalam ilmu lain maupun dalam kehidupan seharihari sehingga kemampuan pemecahan masalah dan koneksi matematisnya meningkat.

4. Tahap terakhir adalah menjelaskan kembali, pada tahap ini siswa menjelaskan kembali isi materi kepada pihak lain. Kegiatan ini memberikan kesempatan bagi siswa melakukan unjuk kerja dan melatih kemampuan siswa dalam mengemukakan pendapat, ide, dan gagasan. Selain itu, dapat memberikan kesempatan interaksi siswa dengan siswa dan siswa dengan guru dalam diskusi. Kebiasaan siswa untuk mengaitkan konsep-konsep yang didapat dalam pembelajaran sebelumnya dengan materi pembelajaran yang sedang didapat mampu meningkatkan kemampuan pemecahan masalah dan koneksi matematis siswa. Peningkatan itu juga didapat melalui pemberian soal-soal latihan maupun pekerjaan rumah yang berkaitan dengan kehidupan sehari-hari maupun ilmu lain. Berdasarkan uraian deskriptif di atas, dapat dilihat bahwa model reciprocal teaching berbantuan masalah autentik berpengaruh positif terhadap kemampuan pemecahan masalah dan koneksi matematis siswa jika dibandingkan dengan pembelajaran konvensional. Hal tersebut juga didukung oleh hasil uji hipotesis yang menunjukan kemampuan pemecahan masalah dan koneksi matematis siswa yang mendapat pembelajaran reciprocal teaching lebih tinggi daripada kemampuan pemecahan masalah dan koneksi matematis siswa yang mendapat pembelajaran konvensional. 


\section{KESIMPULAN}

Kemampuan pemecahan masalah dan koneksi matematis siswa yang mengikuti model pembelajan reciprocal teaching berbantuan masalah autentik lebih tinggi daripada kemampuan pemecahan masalah dan koneksi matematis siswa yang mengikuti pembelajaran konvensional.

\section{REFERENSI}

Aljaberi, N.M., Gheith, E., 2016. Pre-Service Class Teacher'Ability in Solving Mathematical Problems and Skills in Solving Daily problems. High. Educ. Stud.6, 32. https:/doi.org/10.5539/hes.v6n3p32

Kolovou, Angeliki., 2011., Mathematical Problem Solving in Primay School. Utrecht:Freudenthal Institute for Science and Mathematics Education, Faculty of Sciences, Utrecht University, no.66,2011.

NCTM. 1989. "Principles and Standards for School Mathematics. Curriculum and evaluation standards for school mathematics". Tersedia pada http://www.fayar.net/east/teacher.web/Math/Standards/index.htm (diakses tanggal 11 Desember 2017)

2000. Principle and Standards for School Mathematics. Reston VA: NCTM

OECD., 2016. Assesment Framework - Mathematics, Reading, Science and Problem Solving Knowledge and Skills.Paris:OECD.

Ruspiani. 2000. Kemampuan Siswa dalam Melakukan Koneksi Matematis Matematika. Tesis PPS UPI : Tidak diterbitkan

\section{Daftar Pustaka}

Bana, Kartasasmita.,2017. The students of Indonesian's math really apprehensive. Okezone News. Candiasa. 2010a. Pengujian Instrumen Penelitian Disertai Aplikasi ITEMAN dan BIGSTEPS. Singaraja. Unit Penerbitan Universitas Pendidikan Ganesha.

Departemen Pendidikan Nasional. 2006. Permen No. 22 tentang Standar Isi untuk Satuan Pendidikan Dasar dan Menengah. Jakarta: Depdiknas.

Herlambang ,dkk. (2015). Pengaruh Penggunaan Strategi Reciprocal Teaching terhadap Peningkatan Kemampuan Komunikasi Matematis Siswa SMP. Jurnal Pendidikan Matematika "SYMMETRY". 4(1): halaman 521-538.

Herman., dkk. (2014). Penerapan Model Reciprocal Teaching pada Pembelajaran Matematika Siswa Kelas VIII SMPN 26 Padang. Jurnal Pendidikan Matematika. 3(1): halaman 13-17.

Listyotami, M. K. 2011. “ Upaya Meningkatkan Kemampuan Koneksi Matematika Siswa Kelas VII A SMP N 15 Yogyakarta Melalui Model Pembelajaran Learning Cycle “5E”. Skripsi FMIPA UNY: tidak diterbitkan.

Sudiarta, I.G.P \& Sukawijaya.2018. Developing Blended Learning Enviroment to Improve Learning Performance and Self-Reliance for Junior High School Students.

Sugiyono. 2011. Metode Penelitian Pendidikan Pendekatan Kuantitatif, Kualitatif dan R\&D. Bandung : Penerbit Alfabeta.

Polya, G. 1973. How To Solve It ( $2^{\text {nd }}$ Ed). Princenton: Princenton University Pres.

Trianto. 2007. Model-Model Pembelajaran Inovatif Berorientasi Inovatif Konstruktivistik. Jakarta: Prestasi Pustaka.

Trianto. 2009. Mendesain Model Pembelajaran Inovatif-Progresif: Konsep, Landasan, dan Implementasinya pada Kurikulum Tingkat Satuan Pendidikan (KTSP). Jakarta: Kencana Prenada Media Group

Trianto. 2011. Mendesain Model Pembelajaran Inovatif-Progresif. Jakarta: Kencana Prenada Media Group

Whicker, K.M., Bol, L., \& Nunnery, J.A.2010. Cooperatif Learning in The Secondary Mthematics Classroom. The Journal of Educatonal Research, 91(1), 42-48 